\title{
Status of oral polio vaccination program for international travellers and its determinants: an experience from a designated centre of West Bengal
}

\author{
Manisha Sarkar ${ }^{1} *$, Urmila Dasgupta ${ }^{2}$, Saikat Bhattacharya ${ }^{2}$, \\ Krishna Das Bhattacharyya ${ }^{2}$, Salil Kumar Bhattacharya ${ }^{2}$
}

Department of Community Medicine, ${ }^{1}$ Raipur Institute of Medical Sciences, Raipur, ${ }^{2}$ Medical College, Kolkata, India

Received: 06 February 2017

Accepted: 06 March 2017

*Correspondence:

Dr. Manisha Sarkar,

E-mail: misdav2003@gmail.com

Copyright: (C) the author(s), publisher and licensee Medip Academy. This is an open-access article distributed under the terms of the Creative Commons Attribution Non-Commercial License, which permits unrestricted non-commercial use, distribution, and reproduction in any medium, provided the original work is properly cited.

\begin{abstract}
Background: In order to maintain the polio free status of India, it is vital to monitor the ongoing oral polio vaccination for international travellers. The aim of the study was to determine the status of oral polio vaccination program for international travellers from India to polio infected countries and to find out the determinants of deviation from proposed guidelines.

Methods: A descriptive cross-sectional study was conducted among 101 International travellers from November 2014 to April 2015 at a designated Polio vaccination centre for international travellers in Kolkata. A pre-designed pretested schedule was used to collect oral polio vaccination related details. The travellers who gave consent were eligible for the study. Data was expressed in terms of mean, median, standard deviation etc. Association between variables was tested by Chi square test.

Results: $32.7 \%$ of the travellers had inadequate gap between OPV \& travel. Knowledge of gap between OPV and travel was perceived more from health centres and travel agencies than mass media. Inadequate gap was more among lower age group, males, those with information source as mass media, official purpose of visit, those with incorrect knowledge regarding the gap requirement and those who maintained at least four weeks gap between OPV and yellow fever vaccine.

Conclusions: Wrong information from the source is responsible for wrong knowledge among the travellers which leads to inadequate gap between OPV and travel. It is crucial to increase awareness among the vaccinators and international travellers in order to contribute towards global polio eradication.
\end{abstract}

Keywords: OPV, International traveller, adequate gap, Determinants, Polio infected countries

\section{INTRODUCTION}

During the pre vaccination era, entire world map was overshadowed by infectious diseases. One of such crippling infectious disease was poliomyelitis. In the early $20^{\text {th }}$ century this disease paralyzed several thousands of children in a year. With the implementation of poliomyelitis eradication strategies by World Health
Assembly since 1988, this disease has now been eradicated from four regions of World health organization (WHO) i.e. America, Western Pacific, Europe and South East Asia. On 27 ${ }^{\text {th }}$ March 2014 an important milestone was achieved when the South- East Asia Regional Certification Commission for Polio eradication declared the South-East Asia Region of the WHO polio-free. The South-East Asia region of WHO, 
comprising 11 countries, including India, is the fourth region to attain this distinction. ${ }^{1}$ The number of polio endemic countries has been reduced from 125 in 1988 to 3 in 2014. These countries are Afghanistan, Pakistan and Nigeria. India has not reported any polio case since $13^{\text {th }}$ January 2011. The success achieved so far in global polio eradication emphasizes the hard work and dedication of so many health care professionals and workers despite continuous hardships. During 2013, 406 cases of wild polio were reported globally. Of these 160 cases were from endemic countries while the remaining cases were due to international spread from endemic areas into poliofree areas. ${ }^{2}$ The gateway to polio eradication is not an easy game rather emphasizes the persisting challenges yet to overcome. Until poliovirus transmission is interrupted in the endemic countries, all countries remain at risk of importation of polio, especially vulnerable countries with weak public health and immunization services and travel or trade links to endemic countries. ${ }^{3}$ India being a neighbour to Pakistan and Afghanistan as well as the international travelling to or from polio endemic countries poses the greatest threat to importation of polio virus in our country. The WHO Director-General determined that the international spread of wild type poliovirus constitutes a public health emergency of international concern under the International Health Regulations (IHR). As part of this process, the DirectorGeneral has issued specific IHR 'Temporary Recommendations' to all infected countries concerning polio vaccination of international travellers from these countries in order to reduce the international spread of wild poliovirus. ${ }^{4}$ In order to maintain the polio free status and to mitigate the risk of importation of polio virus in India, the Ministry of Health \& Family Welfare (Mohfw), Government of India (GOI) had made mandatory the requirement of one dose of oral polio vaccine (OPV) for international travellers between India and polio endemic countries (Afghanistan, Nigeria, Pakistan) as well as between India and countries with polio virus circulation following importation (Ethiopia, Kenya, Somalia, Syria) irrespective of their age, sex and previous immunization status, effective from 1st March 2014. ${ }^{5,6}$ The list of polio infected countries may be amended from time to time. ${ }^{5}$

But to be effective, this additional dose should be taken at least four weeks prior to departure and is valid for one year from the date of certification. All District Immunization Officers (DIO) or a concerned officer in a vaccination centre designated by DIO can issue this certificate on a standard format. ${ }^{5}$

There is only limited study in literature which evaluates the functioning of ongoing program for international travellers to or from polio endemic countries. But there is no existing study which tries to determine the factors for gap in the existing program for international travellers to or from our country. Whether the gap of minimum four weeks between date of OPV and date of international travel to polio endemic or polio infected countries is maintained or not. Whether the government policies related to international travellers is effectively implemented or not. What factors are responsible for such deviations like less than four weeks gap between OPV and international travel? All of these are crucial to maintain the polio free status and ultimately step towards global polio eradication. With this background the current study was undertaken with an overall aim to determine the status of oral polio vaccination for international travellers from India to polio infected countries and to find out determinants of deviation from proposed guidelines. The specific objectives were to find out determinants of: (i) knowledge regarding the four weeks gap between date of OPV and date of travel to polio infected countries, (ii) knowledge regarding the names of countries for which vaccination required and (iii) the practice of non maintenance of four weeks gap between OPV vaccination and travel to polio infected countries.

\section{METHODS}

An Institution based observational descriptive crosssectional study was conducted for 6 months from November, 2014 to April, 2015 in Medical College, Kolkata. All those international travellers who came for oral polio vaccination during the study period \& gave consent were included in the study. During this study period 101 international travellers who attended Medical College Centre for oral polio vaccination and gave consent were interviewed. All of them were interviewed using a pre designed pre tested semi structured interview schedule. They were enquired about their age, sex, religion, place of residence, date of international journey, country they will visit, date of vaccination, purpose of visit, intake of any other vaccine, gap between 2 vaccines, source of information about OPV, their existing knowledge regarding four weeks gap between international travel and date of OPV, knowledge of the names of countries for which vaccination required etc. Study tool also included OPV certificate and any other vaccination certificate relevant for international travelling. Validation of the schedule was done by the authors. Ethical clearance was obtained from institutional ethics committee. At the end of the interview, the respondents were addressed about their queries regarding oral polio vaccination for international travel and correct knowledge was given regarding the minimum requirements for international travel to polio endemic countries, in order to maintain polio-free status of our country. Data were tabulated in MS-Excel \& descriptive statistics like number, percentage, mean, median, mode, range, standard deviation, gap between date of vaccination and date of journey etc. were calculated. Test of association between dependent and independent variables was tested by chi square test using SPSS-16 and $\mathrm{p}$ value less than 0.05 was considered significant.

\section{RESULTS}

Mean age of the international travellers was $45.31 \pm$ 16.68 years and median age was 48 years with range 
from 4 years to 74 years. Most of them (39.6\%) belonged to the age group of 41-60 years, followed by 21-40 years age group $(26.7 \%)$. Nearly two thirds $(64.4 \%)$ of the travellers were male. Most of the travellers were Hindu (83.2\%) followed by Muslims (9.9\%) and remaining $(7.0 \%)$ were Christian, Sikh and Jain. Most of the vaccine receivers were from Kolkata $(82.2 \%)$ and the remaining $(17.8 \%)$ travellers were from outside Kolkata (13.9\% from other districts of West Bengal \& $4.0 \%$ from other states of India). Four neighbouring districts of Kolkata, i.e. Howrah, Hooghly, North 24 Parganas \& South 24 Parganas accounted for $13.0 \%$ of the residence of international travellers. Remaining $5 \%$ of the total respondents were from Burdwan (1.0\%) and other far off places like Bihar (1.0\%), Jharkhand $(2.0 \%)$ and Lucknow (1.0\%). Socio-demographic characteristics of international travellers have been shown in Table 1. Majority $(97.0 \%)$ of the study population were visiting the seven countries mentioned by WHO \& GOI for which polio vaccination is mandatory while $3.0 \%$ of the passengers were transiting via polio infected counties to South Africa for whom polio vaccination is not needed. $81.2 \%$ of the respondents were visiting the seven designated countries in single trip, $6.9 \%$ of the respondents were having multiple trips to seven designated countries, $8.9 \%$ of the travellers were visiting seven designated countries together with visit to other country (South Africa) while the remaining 3.0\% were travelling to South Africa via polio infected countries. Kenya was the most stated (62.4\% of study population) country of visit by the vaccine receivers followed by Nigeria (28.7\% of study population). Afghanistan was the least visited country with only one visitor. The purpose of visit in nearly two thirds $(65.3 \%)$ of the respondents was tourism while remaining $(34.7 \%)$ were visiting for official purpose.

Table 1: Socio-demographic characteristics of study population $(n=101)$.

\begin{tabular}{|lll|}
\hline Variables & & Number $(\%)$ \\
\hline \multirow{4}{*}{ Age in years } & $<21$ & $9(8.9)$ \\
\cline { 2 - 3 } & $21-40$ & $27(26.7)$ \\
\cline { 2 - 3 } & $41-60$ & $40(39.6)$ \\
\cline { 2 - 3 } Sex & \multicolumn{6}{|c|}{ Male } & $25(24.8)$ \\
\hline \multirow{5}{*}{ Religion } & Female & $65(64.4)$ \\
\hline & Hindu & $36(35.6)$ \\
\cline { 2 - 3 } & Muslim & $84(83.2)$ \\
\cline { 2 - 3 } & Christian & $10(9.9)$ \\
\cline { 2 - 3 } & Jain & $4(1.0)$ \\
\cline { 2 - 3 } Residence & Sikh & $2(2.0)$ \\
\hline & Kolkata district & $83(82.2)$ \\
\cline { 2 - 3 } & Other districts of & $14(13.9)$ \\
\cline { 2 - 3 } & West Bengal & $4(4.0)$ \\
\cline { 2 - 3 } & Other states & \\
\hline
\end{tabular}

Nearly two thirds $(67.3 \%)$ of the international travellers had adequate gap between date of vaccination $\&$ date of journey i.e. 28 days which is necessary for the vaccine dose to be effective while one third $(32.7 \%)$ of the study population had inadequate gap i.e. less than four weeks. Most of the study population received information about OPV from health centre/institution (43.6\%) and travel agencies (43.6\%) followed by mass media (12.9\%). Most $(93.1 \%)$ of the international travellers took yellow fever vaccine apart from OPV. $38.3 \%$ of the travellers who took yellow fever vaccine, took it on the same day with OPV , 29.8\% took the yellow fever vaccine within four weeks and not on same day with OPV and $31.9 \%$ took yellow fever vaccine with at least one month gap with OPV.

Table 2: Factors concerned with visit of international travellers from India to polio infected countries $(n=101)$.

\begin{tabular}{|c|c|c|}
\hline Variables & & Number $(\%)$ \\
\hline \multirow{4}{*}{$\begin{array}{l}\text { Country of } \\
\text { visit }\end{array}$} & $\begin{array}{l}\text { Seven designated } \\
\text { countries single trip only }\end{array}$ & $82(81.2)$ \\
\hline & $\begin{array}{l}\text { Multiple trips to seven } \\
\text { designated countries }\end{array}$ & $7(6.9)$ \\
\hline & $\begin{array}{l}\text { Seven designated } \\
\text { countries and other } \\
\text { countries too }\end{array}$ & $9(8.9)$ \\
\hline & $\begin{array}{l}\text { Transit via seven polio } \\
\text { infected countries }\end{array}$ & $3(3.0)$ \\
\hline \multirow{2}{*}{$\begin{array}{l}\text { Purpose of } \\
\text { visit }\end{array}$} & Official & $35(34.7)$ \\
\hline & Tour & $66(65.3)$ \\
\hline \multirow{2}{*}{$\begin{array}{l}\text { Gap } \\
\text { between } \\
\text { OPV intake } \\
\text { and date of } \\
\text { international } \\
\text { travel }\end{array}$} & < 4 weeks (inadequate) & $33(32.7)$ \\
\hline & $\geq 4$ weeks (adequate) & $68(67.3)$ \\
\hline \multirow{2}{*}{$\begin{array}{l}\text { Any other } \\
\text { vaccine }\end{array}$} & Yes (Yellow fever) & $94(93.1)$ \\
\hline & No & $7(6.9)$ \\
\hline \multirow{4}{*}{$\begin{array}{l}\text { Gap } \\
\text { between } \\
\text { OPV and } \\
\text { yellow fever } \\
\text { vaccine* } \\
(n=94)\end{array}$} & Same day & $36(38.3)$ \\
\hline & 4 weeks & $6(6.4)$ \\
\hline & $\begin{array}{l}\text { Not on same day and }<4 \\
\text { weeks }\end{array}$ & $28(29.8)$ \\
\hline & $>4$ weeks & $24(25.5)$ \\
\hline \multirow{3}{*}{$\begin{array}{l}\text { Information } \\
\text { about OPV }\end{array}$} & Health centre/ institution & $44(43.6)$ \\
\hline & Mass media & $13(12.9)$ \\
\hline & Travel agency & $44(43.6)$ \\
\hline \multirow{3}{*}{$\begin{array}{l}\text { Knowledge } \\
\text { of } 4 \text { weeks } \\
\text { gap between } \\
\text { OPV and } \\
\text { international } \\
\text { travel }\end{array}$} & Don't know & $57(56.4)$ \\
\hline & Know & $38(37.6)$ \\
\hline & Wrong knowledge & $6(5.9)$ \\
\hline \multirow{3}{*}{$\begin{array}{l}\text { Knowledge } \\
\text { of name of } \\
\text { country }\end{array}$} & Don't know & $49(48.5)$ \\
\hline & Partly know & $41(40.6)$ \\
\hline & Know & $11(10.9)$ \\
\hline
\end{tabular}

* Out of the total international travellers who took OPV, 94 travellers also took yellow fever vaccine 
$37.6 \%$ of the study population had correct knowledge regarding requirement of four weeks gap between OPV and travel to polio infected countries, 5.9\% had incorrect knowledge regarding the minimum gap between OPV and travel and the remaining $(56.4 \%)$ had no knowledge regarding the adequate gap between OPV and date of international visit to polio infected countries. Only $10.9 \%$ of the travellers had knowledge of the names of the seven polio infected countries for which polio vaccination was mandatory, $48.5 \%$ had no knowledge regarding the names of countries while $40.6 \%$ of the respondents had partial knowledge of the names of the countries for which OPV was required. Factors concerned with visit to polio infected countries from India by international travellers, has been shown in Table 2.

Table 3: Association between socio-demographic and other factors with knowledge of 4 weeks gap between OPV and international travel $(n=101)$.

\begin{tabular}{|c|c|c|c|c|c|c|c|c|c|}
\hline \multirow[b]{2}{*}{ Variables } & & \multicolumn{3}{|c|}{ Knowledge of 4 weeks } & \multicolumn{5}{|c|}{ Test statistics } \\
\hline & & $\begin{array}{l}\text { Don't } \\
\text { know } \\
\text { or wrong } \\
\text { knowledge } \\
\text { n (\%) } \\
63(62.4)\end{array}$ & $\begin{array}{l}\text { Know } \\
\text { n (\%) } \\
38(37.6)\end{array}$ & $\begin{array}{l}\text { Total } \\
\mathrm{n}(\%) \\
101 \\
(100.0)\end{array}$ & $\chi^{2}$ & $\mathrm{df}$ & $\mathrm{p}$ & OR & $\begin{array}{l}95 \% \\
\text { CI }\end{array}$ \\
\hline \multirow{2}{*}{ Age (years) } & $<48$ & $32(65.3)$ & $17(34.7)$ & $49(100.0)$ & \multirow{2}{*}{0.348} & \multirow{2}{*}{1} & \multirow{2}{*}{0.555} & 1.27 & \multirow{2}{*}{$\begin{array}{l}0.568- \\
2.861\end{array}$} \\
\hline & $\geq 48$ & $31(59.6)$ & $21(40.4)$ & $52(100.0)$ & & & & 5 & \\
\hline \multirow{2}{*}{ Sex } & Male & $42(64.6)$ & $23(35.4)$ & $65(100.0)$ & \multirow{2}{*}{0.390} & \multirow{2}{*}{1} & \multirow{2}{*}{0.533} & 1.30 & \multirow{2}{*}{$\begin{array}{l}0.566- \\
3.007\end{array}$} \\
\hline & Female & $21(58.3)$ & $15(41.7)$ & $36(100.0)$ & & & & 4 & \\
\hline \multirow{3}{*}{$\begin{array}{l}\text { Information } \\
\text { centre }\end{array}$} & Health centres/ institution & $32(72.7)$ & $12(27.3)$ & $44(100.0)$ & \multirow{3}{*}{10.117} & \multirow{3}{*}{2} & \multirow{3}{*}{0.006} & \multirow{3}{*}{-} & \multirow{3}{*}{-} \\
\hline & Mass media & $11(84.6)$ & $2(15.4)$ & $13(100.0)$ & & & & & \\
\hline & Travel agency & $20(45.5)$ & $24(54.5)$ & $44(100.0)$ & & & & & \\
\hline \multirow{2}{*}{$\begin{array}{l}\text { Purpose of } \\
\text { visit }\end{array}$} & Service related/ official & $21(60.0)$ & $14(40.0)$ & $35(100.0)$ & \multirow{2}{*}{0.129} & \multirow{2}{*}{1} & \multirow{2}{*}{0.720} & \multirow{2}{*}{$\begin{array}{l}0.85 \\
7\end{array}$} & \multirow{2}{*}{$\begin{array}{l}0.369 \\
1.989\end{array}$} \\
\hline & Tour & $42(63.6)$ & $24(36.4)$ & $66(100.0)$ & & & & & \\
\hline
\end{tabular}

Table 4: Association between socio-demographic and other factors with knowledge of name of polio infected countries $(n=101)$.

\begin{tabular}{|c|c|c|c|c|c|c|c|c|c|}
\hline \multirow[b]{2}{*}{ Variables } & & \multicolumn{3}{|c|}{ Knowledge of name of country } & \multicolumn{5}{|c|}{ Test statistics } \\
\hline & & $\begin{array}{l}\text { Don't } \\
\text { know or } \\
\text { partly } \\
\text { know } \\
\text { n }(\%) \\
90(89.1)\end{array}$ & $\begin{array}{l}\text { Know } \\
\mathrm{n}(\%) \\
11(10.9)\end{array}$ & $\begin{array}{l}\text { Total } \\
\mathrm{n}(\%) \\
101(100.0)\end{array}$ & $\chi^{2}$ & df & $\mathrm{p}$ & OR & $95 \% \mathrm{CI}$ \\
\hline \multirow{2}{*}{ Age (years) } & $<48$ & $42(85.7)$ & $7(14.3)$ & $49(100.0)$ & \multirow{2}{*}{1.130} & \multirow{2}{*}{1} & \multirow{2}{*}{0.288} & \multirow{2}{*}{0.5} & $0.137-$ \\
\hline & $\geq 48$ & $48(92.3)$ & $4(7.7)$ & $52(100.0)$ & & & & & 1.828 \\
\hline \multirow{2}{*}{ Sex } & Male & $58(89.2)$ & $7(10.8)$ & $65(100.0)$ & \multirow{2}{*}{0.003} & \multirow{2}{*}{1} & \multirow{2}{*}{0.958} & \multirow{2}{*}{1.036} & $0.282-$ \\
\hline & Female & $32(88.9)$ & $4(11.1)$ & $36(100.0)$ & & & & & 3.808 \\
\hline \multirow{3}{*}{$\begin{array}{l}\text { Information } \\
\text { centre }\end{array}$} & $\begin{array}{l}\text { Health } \\
\text { centres/ } \\
\text { institution }\end{array}$ & $37(84.1)$ & $7(15.9)$ & $44(100.0)$ & \multirow{3}{*}{3.238} & \multirow{3}{*}{2} & \multirow{3}{*}{0.198} & \multirow{3}{*}{-} & \multirow{3}{*}{-} \\
\hline & Mass media & $11(84.6)$ & $2(15.4)$ & $13(100.0)$ & & & & & \\
\hline & $\begin{array}{l}\text { Travel } \\
\text { agency }\end{array}$ & $42(95.5)$ & $2(4.5)$ & $44(100.0)$ & & & & & \\
\hline \multirow[t]{2}{*}{$\begin{array}{l}\text { Purpose of } \\
\text { visit }\end{array}$} & $\begin{array}{l}\text { Service } \\
\text { related/ } \\
\text { official }\end{array}$ & $31(88.6)$ & $4(11.4)$ & $35(100.0)$ & \multirow[t]{2}{*}{0.016} & \multirow[t]{2}{*}{1} & \multirow[t]{2}{*}{0.9} & \multirow[t]{2}{*}{0.919} & \multirow[t]{2}{*}{$\begin{array}{l}0.250- \\
3.384\end{array}$} \\
\hline & Tour & $59(89.4)$ & $7(10.6)$ & $66(100.0)$ & & & & & \\
\hline
\end{tabular}

The association between the socio-demographic and other determinants with knowledge of four weeks gap between
OPV and international travel has been shown in Table 3. There is an association between knowledge of four weeks 
gap and source of information. It was revealed that correct knowledge of four weeks gap was more among those whose source of information were travel agency $(63.2 \%)$ followed by health centers or institutions $(31.6 \%)$ and least among those with information source as mass media $(5.3 \%)$. This was statistically significant $\left(\chi^{2}=10.117, \mathrm{df}=2\right.$ and $\left.\mathrm{p}=0.006\right)$. However, there was no association between other variables like age, sex, religion and purpose of visit with the knowledge of four weeks gap between OPV and international travel to polio infected countries.

Table 5: Association between socio-demographic and other factors with practice of 4 weeks gap between OPV and international travel $(\mathbf{n}=\mathbf{1 0 1})$.

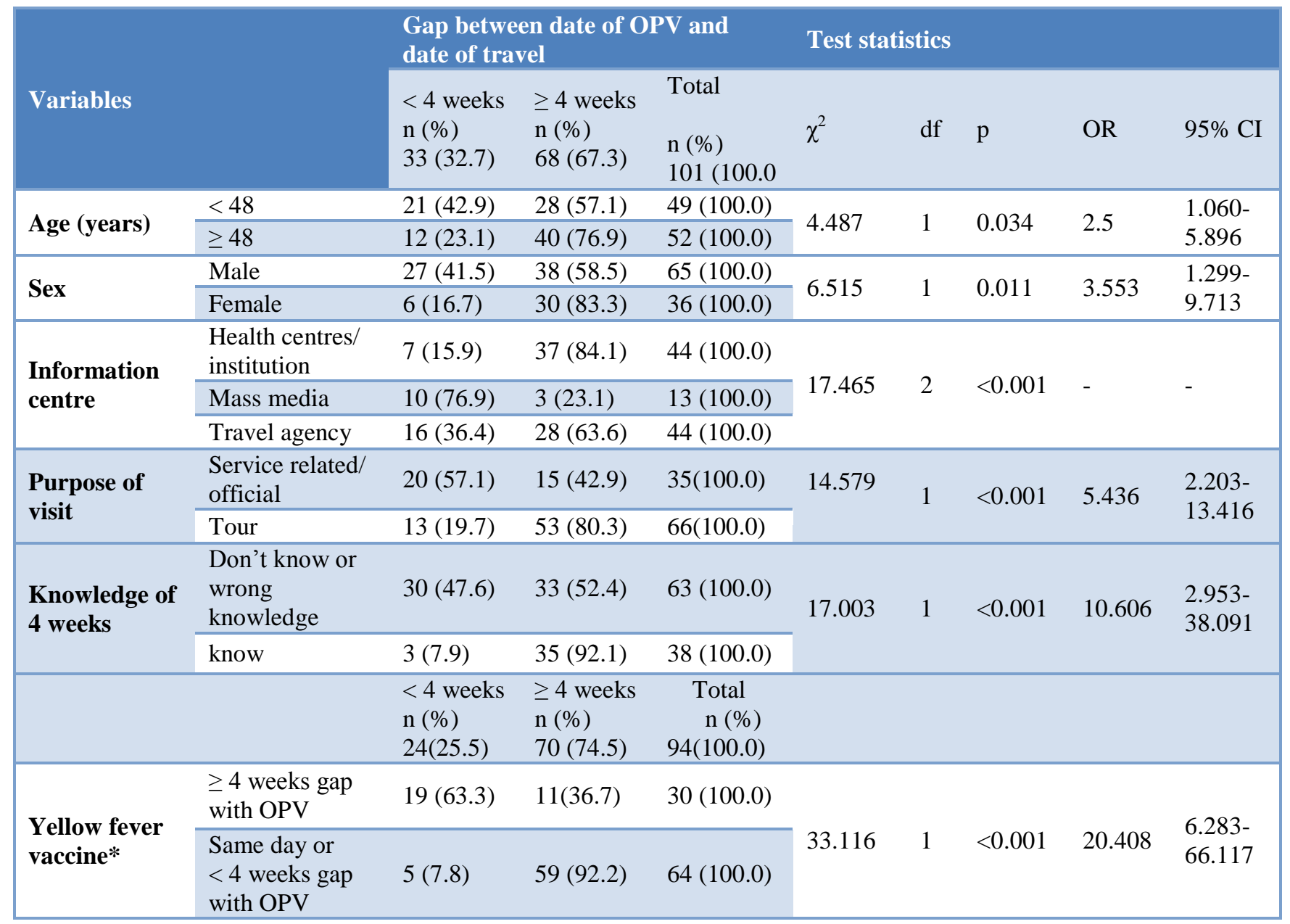

* Out of the total international travellers who took OPV, 94 travellers also took yellow fever vaccine.

Table: 6: Association of gap between yellow fever and OPV with source of information regarding vaccination for international travellers from India $(n=94 *)$.

\begin{tabular}{|c|c|c|c|c|c|c|c|}
\hline \multirow[b]{2}{*}{ Variables } & & \multicolumn{3}{|c|}{ Yellow fever vaccine } & \multicolumn{3}{|c|}{ Test statistics } \\
\hline & & $\begin{array}{l}\text { same day or } \\
<4 \text { weeks gap } \\
\text { with OPV } \\
\text { n }(\%) \\
64(68.1)\end{array}$ & $\begin{array}{l}\geq 4 \text { weeks gap } \\
\text { with OPV } \\
\text { n }(\%) \\
30(31.9)\end{array}$ & $\begin{array}{l}\text { Total } \\
\text { n }(\%) \\
94(100.0)\end{array}$ & $\chi^{2}$ & df & $\mathrm{p}$ \\
\hline \multirow{3}{*}{$\begin{array}{l}\text { Information } \\
\text { centre }\end{array}$} & Health centres/ institution & $21(48.8)$ & $22(51.2)$ & $43(100.0)$ & \multirow{3}{*}{13.557} & \multirow{3}{*}{2} & \multirow{3}{*}{0.001} \\
\hline & Mass media & $7(87.5)$ & $1(12.5)$ & $8(100.0)$ & & & \\
\hline & Travel agency & $36(83.7)$ & $7(16.3)$ & $43(100.0)$ & & & \\
\hline
\end{tabular}

* Out of the total international travellers who took OPV, 94 travellers also took yellow fever vaccine. 
The association between the socio-demographic and other variables with the knowledge of the names of seven polio infected countries for which polio vaccination was mandatory has been shown in Table 4. It was observed that there is no association of age, sex, information centre and purpose of visit with the knowledge of names of polio infected countries.

The association between socio-demographic and other variables with the practice of four weeks gap between OPV and international travel to polio infected countries has been shown in Table 5. Inadequate gap between OPV and travel was commoner $(63.6 \%)$ among travellers less than the median age (48 years) compared to the travellers more than or equivalent to median age $(36.4 \%)$. This association was statistically significant $(\mathrm{OR}=2.5$; $\mathrm{CI}=1.060-5.896)$. The gap of less than four weeks between OPV and travel was more common among males $(81.8 \%)$ compared to females $(18.2 \%)$. This relation was statistically significant $(\mathrm{OR}=3.6 ; \mathrm{CI}=1.299-9.713)$. There was an association between the source of information about OPV and the practice of four weeks gap between OPV and international travel. The present study revealed that those who got the information about vaccination for international travellers from heath centres /institution had higher percentage $(84.1 \%)$ of international travellers who maintained adequate gap between OPV vaccination and travel to polio infected countries than those who got the information from travel agencies $(63.6 \%)$ and mass media $(23.1 \%)$. This was also statistically significant $\left(\chi^{2}\right.$ $=17.465, \mathrm{df}=2$ and $\mathrm{p}<0.001)$. It was found that those who were going for tour purpose maintained adequate gap more $(80.3 \%)$ than those who were going for official purpose $(42.9 \%)$. This was statistically significant $(\mathrm{OR}=5.436 ; \mathrm{CI}=2.203-13.416)$. In the present study it was found that the practice of inadequacy in gap between OPV and travel was more among those who had wrong knowledge or partial knowledge regarding the minimum gap requirements $(90.9 \%)$ than those who had correct knowledge $(9.1 \%)$, where as those who had complete knowledge of minimum gap between OPV and travel, among them the practice of maintenance of adequate gap was more $(92.1 \%)$ than non maintenance of adequate gap $(7.9 \%)$. This association was statistically significant $(\mathrm{OR}=10.606 ; \mathrm{CI}=2.953-38.091)$. Inadequacy in practice of gap between OPV and travel was more among those individuals who had maintained at least four weeks gap between OPV and yellow fever vaccine (79.2\%) than those who took OPV on the same day or less than four weeks gap with Yellow fever vaccine (20.8\%). This association was statistically significant $(\mathrm{OR}=20.408$; $\mathrm{CI}=6.283-66.117)$.

Among the total international travellers who took yellow fever vaccine, the maintenance of at least four weeks gap between OPV and yellow fever vaccine was more among those whose source of information was health centres/ institutions $(73.3 \%)$ rather than travel agencies $(23.3 \%)$ and mass media (3.4\%). This association was statistically significant $\left(\chi^{2}=13.557, \mathrm{df}=2\right.$ and $\left.\mathrm{p}=0.001\right)$. The association of gap between yellow fever and OPV with source of information regarding vaccination for international travellers from India has been shown in Table 6.

\section{DISCUSSION}

A descriptive cross sectional study was conducted among the international travellers going to polio infected countries attending a designated centre of West Bengal for OPV with the aim to determine the status of oral polio vaccination for international travellers from India and to find out the determinants of deviation from proposed guidelines. Keeping in view the polio end game strategic plan it is important to adhere to the guidelines given by the Ministry of health and family welfare. Though the oral polio vaccination program for international travellers is being operational since March 2014, yet there are hardly any research work related to the ongoing status of such programs except the study conducted by Dasgupta et al. ${ }^{7}$ Furthermore, there are no studies in the existing literature regarding the factors behind deviation from the proposed oral polio vaccination program for international travellers.

In the present study the mean age of the international travellers was $45.31 \pm 16.68$ years. This was similar to the previous work of author Dasgupta et al. where the mean age of respondents was $43.21 \pm 16.31$ years. $^{7}$ In this study majority $(64.4 \%)$ of the respondents were male similar to the previous work of Dasgupta et al. where majority $(72.5 \%)$ were males. ${ }^{7}$ In the present study majority of the travellers was Hindu (83.2\%). This was similar to the author's previous study as mentioned above where majority were Hindu (88\%). In the present study it was revealed that $17.9 \%$ of the travellers were from outside Kolkata despite of the Mohfw guidelines that each district in India has designated at least one centre where vaccine with OPV will be provided to travellers and certificate will be issued. ${ }^{6}$ However in the previous study by the author $40 \%$ of the travellers were from outside Kolkata. So it seems that with better awareness in comparison to past, the outsider's proportion has been decreased with time. The study revealed that majority (97\%) of the travellers were going to polio infected countries with or without multiple trip to same or other countries while $3 \%$ were transiting through polio infected countries and took OPV, for whom oral polio vaccination was not required. In the previous study done by Dasgupta et al. it was found that $10.1 \%$ of the study subjects were visiting countries other than the seven countries mentioned by WHO \& GOI for which polio vaccination is mandatory and took OPV. ${ }^{7}$ These differences could be again due to increase in awareness regarding the name of country with time. The four weeks interval between oral polio vaccine and date of journey could not be maintained by nearly one third $(32.7 \%)$ of the travellers in the present study while in the authors previous study nearly half of the travellers $(46.6 \%)$ had inadequate gap. Though the inadequacy in gap is still there but this is 
definitely less compared to the previous study and reflects the increase in the knowledge of adequate gap and still points towards further need to increase awareness among the international travellers. $62.3 \%$ of the international travellers had either no knowledge or wrong knowledge regarding the gap between OPV and travel. $89.1 \%$ of the travellers had no or partial knowledge of the names of countries for which polio vaccination is mandatory. $93.1 \%$ of the international travellers also had history of yellow fever vaccination, out of which only $38.3 \%$ of the travellers took yellow fever vaccine on the same day with OPV. According to $\mathrm{WHO}$, oral polio vaccine may be given at any time in relation to Yellow Fever vaccination. ${ }^{8}$ The correct knowledge of four weeks gap between OPV and international travel was more among those whose source of information was health centres or travel agencies in comparison to mass media. Thus correct knowledge of four weeks gap between OPV and travel depended upon the source of information.

Adequacies in practice of four weeks gap between OPV and travel were higher among above the median age group reflecting inadequacies more at lower age groups. Practice of adequate gap between OPV and travel was more among those who got the information from health centres and travel agencies rather than mass media. Similarly correct practice of gap between OPV and travel was more among those who were going for tour purpose rather than those who were going for official purpose. This reflects that official purpose of visit was an important determinant of incorrect practice of gap between OPV and travel and that could be because of time constraint and no prior intimation by officials. Those who were going for tour purpose might not have time constraint and therefore better practice of adequate gap requirements. The incorrect practice of gap between OPV and travel was more among those who had no knowledge or wrong knowledge regarding the gap requirements between OPV and international travel. Inadequate gap between OPV and travel was more among those individuals who had maintained at least four weeks gap between OPV and yellow fever vaccine than those who took OPV on the same day or within four weeks of yellow fever vaccine. This was because of lack of adequate knowledge regarding the fact that oral polio vaccine may be given at any time in relation to yellow fever vaccine. The travellers not knowing it gave a gap of four weeks from yellow fever vaccine to OPV thus, the gap between OPV and journey was not maintained. More so, the maintenance of unnecessary four weeks gap between OPV and yellow fever was observed more among those who received information from health institutions than travel agencies and mass media.

Funding: No funding sources

Conflict of interest: None declared

Ethical approval: The study was approved by the Institutional Ethics Committee

\section{REFERENCES}

1. WHO South-East Asia Region certified polio free [Internet]. New Delhi: 2014 Mar 27 Available from: http://www.searo.who.int/mediacentre/ releases/2014/pr1569/en/. Accessed 16 Jan 2017.

2. Park K. Park's textbook of preventive and social medicine. 23rd ed. Jabalpur: Banarsidas Bhanot publishers; chapter 5, Epidemiology of communicable disease. Poliomyelitis; 2015: 203.

3. Global Polio Eradication initiative. Where we workendemic countries. Available from: http://polioeradication.org/where-we-work/polioendemic-countries/. Accessed 16 Jan 2017.

4. International travel and health. World - Polio vaccination for travellers. 2014 Jun 12. Available from: http://www.who.int/ith/updates/20140612/en/. Accessed 16 Jan 2017.

5. Taneja DK. Eradication of poliomyelitis. In: Banerjee B, editor. Health policies and programmes in India, 13th edn. Delhi: Doctors publications; 2015: 185.

6. Ministry of Health and Family Welfare, Government of India. Requirements of polio vaccination for International travellers between India and polio infected countries. New Delhi: 2014. Available from: http://mohfw.nic.in/showfile.php?lid=2634. Accessed 16 Jan 2017.

7. Dasgupta U, Bhattacharya S, Sarkar M, Bhattacharya S K, Bhattacharyya K D. Appraisal of oral polio vaccination for international travellers in a designated centre of West Bengal. IOSR-JDMS. 2015;14(12 version 8):7-10.

8. WHO. Vaccines and vaccination against yellow fever. WHO Position paper-June 2013. Weekly Epidemiological Record (WER). 2013 Jul 5; 2013:283. Available from: http://www.who.int/ wer/2013/wer8827.pdf. Accessed 16 Jan 2017.

Cite this article as: Sarkar M, Dasgupta U, Bhattacharya S, Bhattacharyya KD, Bhattacharya SK. Status of oral polio vaccination program for international travellers and its determinants: an experience from a designated centre of West Bengal. Int J Community Med Public Health 2017;4:1223-9. 